Олександра Божок, кандидат педагогічних наук, доцент

Національний педагогічний університет імені М. П. Драгоманова ORCID ID 0000-0002-0961-9008

Валентин Златніков, кандидат педагогічних наук, доцент, Військовий інститут Київського національного університету імені Тараса Шевченка ORCID ID 0000-0001-7019-9551

\title{
УПРОВАДЖЕННЯ КОМПЕТЕНТНІСНОГО ПІДХОДУ В ОСВІТНІЙ ПРОСТІР ВИЩОЇ ШКОЛИ
}

У статті розкрито поняття компетентнісного підходу в контексті підготовки фахівиів іноземних мов, вказано на види та його особливості. Сучасною парадигмою вищої професійної освіти визнано компетентнісний підхід як один із напрямів оновлення професійної освіти, покликаний розв'язувати суперечності між потребами суспільної практики в компетентних фахівиях та можливостями змісту й методів забезпечення їхньої підготовки.

Ключові слова: компетентність; компетентнісний підхід; фахівець іноземної мови (англійська); педагогічні умови; професійна компетенція.

Постановка проблеми. Проблема компетентності особистості взагалі та професійної зокрема зумовлює впровадження в освіту компетентнісного niдxодy. Згідно з Національним освітнім глосарієм під компетентнісним підходом розуміють визначення результатів навчання у школі й ВНЗ через їх опис у поняттях компетентностей, тобто динамічного поєднання знань, умінь, навичок, здатностей, особистісних якостей та ефективної продуктивної діяльності тощо.

Мета статті. Для з'ясування сутності поняття «компетентнісний підхід» визначимо зміст «підходу». У науковій літературі поняття «підхід» тлумачиться двояко - 3 позиції об'єкта, що досліджується, і з погляду загальної стратегії діяльності. Сутність його розкривається через розуміння як кута зору, сукупності принципів, що визначають мету і зміст роботи, або як пізнавального засобу, методу, інструменту пізнання та способу перетворення дійсності.

У педагогічних наукових виданнях поняття «nidxid» розглядається як «...сукупність прийомів, способів впливу на будь-кого, будь-що, при вивченні будь-чого. Підхід охоплює сукупність ідей, концепцій, розпоряджень, що визначають спосіб розгляду й конструювання дидактичних об'єктів, до яких відносять процес навчання та його складові: мету, зміст навчання, методи, форми процесу навчання, показники результативності» $[2$, $151]$.

Методи дослідження. У нашій статті ми дотримувалися теоретичних методів дослідження, а саме: ретроспективний, проблемно-цільовий та 
міждисциплінарний аналіз із методів вивчення дидактичної, методичної та лінгвістичної літератури, а також аналіз нормативних документів із питань оновлення змісту освіти у вищих педагогічних навчальних закладах України.

Аналіз останніх досліджень i публікацій. Теоретичний доробок із проблеми компетентнісного підходу знаходимо в наукових працях Н. Бібік [2], В. Бондаря [3], С. Бондаря [4], I. Зимньої [5], А. Овчарук [175], О. Савченко [8], А. Хуторського [9] та ін. Учені пропонують різні варіанти осмислення сутності цього поняття, зокрема як узагальнену умову здатності людини ефективно діяти за межами навчальних задач і навчальних ситуацій, сукупність загальних принципів визначення цілей освіти, добору змісту освіти, організації освітнього процесу й оцінювання результатів, оновлення змісту освіти з огляду на мінливу соціально-економічну реальність (I. Фрумін [10]).

Доречними у з'ясуванні ключових понять є напрацювання зарубіжних учених. Так, американські науковці в галузі психології та педагогіки Т. Кроул, С. Камінскі, Д. Поделл доводять, що професіонали відрізняються від інших працівників рівнем компетентності, що має вияв в ухваленні незалежних рішень і вмінні орієнтуватися в питаннях, пов'язаних зі своєю безпосередньою роботою [12].

У проекті профілю вчителя іноземних мов швейцарські вчені виокремлюють три види компетентностей: персональну, соціальну та спеціальну, що підпорядковані інтеркультурній компетентності.

Французькі дослідники оперують таким поняттям, як «мінімальні компетенції» спеціаліста. Наприклад, Вівіан де Ландшеєр пише: «...компетентність - це такий рівень навченості, який потрібен громадянам, щоб успішно функціонувати в суспільстві» [12, с. 27]. Учена визначає компетентність як поглиблене знання або засвоєне вміння, а мінімальну компетенцію як особливий рівень знань і вмінь.

Канадські дослідники Є. Джимез, М. Леннон, П. Мерсер, Х. Мурей і М. Робінсон під педагогічною компетентністю розуміють не тільки знання свого предмета (змістова компетентність), а й педагогічні знання і вміння, до яких відносять комунікативність, добір ефективних методів викладання матеріалу, уміння працювати з учнями, які мають різні рівні навченості [11].

Виклад основного матеріалу. 3 узагальнень результатів запровадження компетентнісного підходу в українській освіті спостерігаємо різноголосся, суперечливі погляди й міркування. Тобто йдеться про розвиток таких освітніх компетенцій, що охоплюють сферу освітніх галузей і навчальних предметів та уможливлюють комплексне досягнення освітніх цілей.

3 аналізу наукових позицій вчених 3'ясовуємо, що вони мають різні відтінки трактування. У педагогічних словниках поняття «компетентність» визначається як: «...володіння знаннями, що дають змогу судити про щонебудь, висловлювати вагому, авторитетну думку», «...поінформованість, обізнаність, авторитетність того, хто... має достатні знання в якій-небудь 
галузі, з чим-небудь добре обізнаний, тямущий, грунтується на знанні, кваліфікований» [1].

Компетентний фахівець повинен мати такий набір компетентностей, що б допомагали йому соціалізуватися в різних життєвих і професійних умовах. Тому компетентним вважається не фахівець, який має енциклопедичні знання, а, навпаки, той, хто здатний соціалізувати наявні знання відповідно до реалій сьогодення.

На переконання Н. Бібік [2] і С. Бондар [4, 9], компетенція не може бути визначена через суму знань та вмінь. Поділяємо їхні погляди, оскільки вони розкривають особистість, яка здатна розв'язувати проблеми не тільки засвоєння готової інформації, а й інтенсивної участі розуму, нагромадженого досвіду, творчих здібностей. Учені відносять компетенцію до потенційної, ідеальної, нормативної, моделювальної якості особистості; компетентність - до актуальної, реальної, формувальної особистісної якості, що існує «тут і зараз». Тобто компетентність є актуалізацією та персоніфікацією компетенції.

Зокрема I. Зимня ідентифікує ці поняття із внутрішніми, психологічними новоутвореннями (знання, уявлення, програми дій, системи цінностей i ставлень), що згодом виявляються в компетентностях людини як актуальні, діяльнісні прояви. Таким чином, компетентність $є$ інтелектуально та особистісно зумовленою соціально-професійною характеристикою життєдіяльності людини, що грунтується на знаннях і иінностях [5, с. 22]. Учена виокремлює групи компетенцій, що мають сенс для нашого дослідження, а came:

1) компетенції, що стосуються людини як особистості (здоров'язберігаюча компетенція, ціннісно-смислова орієнтація у світі, розширення та інтеграція знань, громадянська позиція, самовдосконалення, саморегуляція, саморозвиток);

2) компетенції, що мають відношення до соціальної взаємодії людини та соціальної сфери (соціальна взаємодія, співпраця, толерантність, сприйняття іншого, соціальна мобільність, компетентність у різних видах спілкування);

3) компетенції, що стосуються діяльності людини (пізнавальна діяльність, постановка й розв'язання пізнавальних завдань, компетенція в різних видах діяльності, інформаційно-комунікаційна компетенція) тощо.

Названі компетенції, які виявляються в поведінці й діяльності людини, стають ії особистісними якостями, а отже, компетентностями, що вирізняються певними компонентами. Зокрема мотиваційним (готовність людини до прояву особистих властивостей в діяльності), когнітивним (знання засобів, способів, програм виконання дій, розв'язання соціальних і професійних завдань, засвоєння норм та правил, що становлять зміст компетенцій), операційноповедінковим (досвід реалізації знань, умінь), ціннісно-смисловим (відношення до змісту компетенції, iï особистісна значущість), емоційно-вольовим компонентом (здатність регулювати прояви компетентностей відповідно до контексту і змісту ситуацій соціальної та професійної взаємодії) [77]. 
Отже, у вітчизняній психолого-педагогічній науці найбільш широко аналізуються компетентності, необхідні для діяльності в різних сферах суспільного життя, а компетентнісний підхід вважається ключовим методологічним інструментом для досягнення освітніх цілей.

Щодо впровадження компетентнісного підходу в навчальний процес із вивчення іноземної мови у вищій, середній і початковій школі, то зарубіжні й вітчизняні вчені відстоюють одностайну позицію. За їх переконаннями, 3 втіленням компетентнісного підходу акценти зміщуються з процесу набуття нормативно визначених знань, умінь і навичок у площину формування i розвитку в учнів/студентів здатності творчо застосовувати їх у різних ситуаціях та практично діяти. Із цього виходить, що у своїй навчальновиховній діяльності викладач надає більшого значення організаційноуправлінському аспекту порівняно з інформаційним. У першому випадку він відіграє роль організатора освітньої діяльності, у другому - «ретранслятора знань».

Процес учіння наповнюється розвивальною функцією, що стає інтегрованою характеристикою навчання. Така характеристика має сформуватись у процесі навчання й поєднувати в собі знання, уміння, навички, ставлення, досвід діяльності та поведінкові моделі особистості [7].

Учені Європи та України досліджують професійну компетентність як інтегративну властивість особистості. Так, становлення професійної компетентності майбутніх фахівців залежить від сформованості таких видів компетентностей:

1) спеціальної і професійної;

2) методичної;

3) соціально-психологічної й педагогічної у сфері спілкування із суб'єктами навчальної взаємодії.

Таким чином, поняття професійної компетентності має спільний знаменник в інтерпретації означень, грунтується на знаннях, уміннях, навичках, досвіді та цінностях, набутих у навчанні, діях особистості адекватних можливим життєвим ситуаціям, та вмінні конструктивно їх розв'язувати, здатності обгрунтовано робити вибір, відповідати за результати своєї діяльності, мобілізовувати набуті знання, ставленні особистості до своєї компетенції та предмета діяльності.

Варто зауважити, що деякі вчені ототожнюють компетентності та компетенції, наголошуючи на їх практичній спрямованості, i визначаючи останні у сфері існуючих відносин, - «...між знанням і дією в людській практиці». Натомість розробники «Стратегії модернізації змісту загальної освіти» вважають, що компетентність завжди $\epsilon$ актуальним проявом компетенцій і містить не лише когнітивну й операційно-технологічну складові, а й мотиваційну, етичну, соціальну й рефлексивну.

Отже, компетентності охоплюють якості людини, що дають їй змогу інтегруватись у світовий соціокультурний контекст. 
Попри достатньо великий діапазон наукових тлумачень понять «компетенція» $\mathrm{i}$ «компетентність» для нашого дослідження важливими є такі їх визначення: компетенція - наперед задані вимоги до освітньої підготовки, сукупності знань, способів діяльності, коло повноважень, досвіду, якостей особистості; компетентність - набута якість, застосування набутих знань і відповідних умінь, навичок людини як суб'єкта професійної діяльності, опанування відповідної компетенції і здатність іiі реалізувати у фахово орієнтованих ситуаціях.

У навчальному процесі вищої школи компетентність $є$ інтегрованим результатом освіти особистості. На перший план висуваються чинники формування та розвитку вмінь діяти, використовувати досвід в умовах проблемних ситуацій (наприклад, несприятливі умови праці, нестача інформації, обмаль часу для пошуку відповіді, нез'ясовані причиннонаслідкові зв'язки, недосконалість типових варіантів рішення тощо). Саме в такому сенсі створюються умови для використання механізмів компетентності - здатності діяти в конкретних умовах i завдяки усвідомленим мотивам досягати результату.

Упровадження компетентнісного підходу в освітній простір вищої школи набуває особливого статусу не тільки у справі накопичення знань та їх передачі, а й в розвитку здатності самостійно застосовувати набуті знання, уміння і навички у процесі індивідуального та професійного саморозвитку, самореалізації і самооцінювання.

Таким чином, для впровадження у практику школи компетентнісного підходу потрібно опрацювати новий теоретичних базис, ідентифікувати понятійний фонд європейської педагогічної термінології та узгодити ii 3 вітчизняною наукою, запропонувати ієрархію вимог до освітніх результатів, які б становили об'єктивну оцінку й були зрозумілими всім учасникам навчального процесу в умовах суб'єкт-суб'єктної взаємодії.

Здобутки вчених слугують визначальними орієнтирами у тлумаченні такого виду професійної компетентності, як мовно-методична в контексті підготовки майбутніх фахівців вищої школи.

Однією 3 основних вимог вищої освіти, на думку науковців, $\epsilon$ підготовка особистості-професіонала, його призначення та ролі в суспільстві.

Висновки та перспективи подальших досліджень. Сучасною парадигмою вищої професійної освіти визнано компетентнісний підхід як один із напрямів оновлення професійної освіти, покликаний розв'язувати суперечності між потребами суспільної практики в компетентних фахівцях та можливостями змісту й методів забезпечення їх підготовки.

Основними положеннями компетентнісного підходу $є$ : встановлення зв'язку освітнього процесу у вищому навчальному закладі 3 вимогами зовнішнього середовища 3 метою удосконалення професійної підготовки майбутнього вчителя із сформованою системою професійних компетенцій. Йдеться про відкриту систему, що постійно розвивається й наповнюється новим змістом, визначається рівнем розвитку особистості у всіх іiі сферах, 
формується в діяльності й орієнтована на задоволення запитів суспільства та потреб студентів (учнів). Складниками професійної компетентності фахівця виступають необхідні для виконання професійної діяльності знання, уміння, професійно значущі здатності та якості особистості.

В освітньому просторі ВНЗ підготовка майбутніх фахівців іноземної мови у початкових класах розглядається як процес реалізації компетентнісного підходу в умовах індивідуального саморозвитку, самовдосконалення та самореалізації набутої професійної компетентності в педагогічній діяльності.

Відповідно професійну компетентність розглядаємо як здатність користуватись іноземною мовою у професійних цілях, вивчаючи іноземну мову з опором на свої вікові особливості та пізнавальні можливості.

\section{ЛІТЕРАТУРА}

1. Азимов Э. Г., Щукин А. Н. Словарь методических терминов / С. Г. Алимов. СПб: Златоуст, 1999. - 365 с.

2. Бібик Н. М. Компетентність і компетенції у результатах початкової освіти / Н. М. Бібік // Початкова школа. - 2010. - № 9. - С. 1-4.

3. Бондар В. І. Формування компетентності та конкурентоздатності випускника педагогічного ВНЗ / В. І. Бондар // Науковий часопис НПУ імені М. П. Драгоманова. Серія: теорія і практика навчання та виховання ; зб. наук. праць. - К. : вид-во НПУ імені М. П. Драгоманова, 204 с.

4. Бондар С. Компетентність особистості - інтегрований компонент навчальних досягнень учнів / С.Бондар . - 2003. - Науковий часопис НПУ імені М. П. Драгоманова. Серія: теорія і практика навчання та виховання ; зб. наук. праць. - К. : вид-во НПУ імені М. П. Драгоманова. - С. 11-15.

5. Зимняя И. А. Ключевые компетентности как результативно-целевая основа компетентностного подхода в образовании. Авторская версия / И. А. Зимняя. - М. : Исследовательский центр проблем качества подготовки специалистов, 2004. - 42 с.

6. Овчарук О. Компетентності як ключі до оновлення змісту освіти / Оксана Овчарук // Стратегія реформування освіти в Україні: рекомендації з освітньої політики. - К. : К. І. С., 2003. C. 17-27.

7. Пометун О. І. Компетентністний підхід до оцінювання рівнів досягнень учнів / О. І. Пометун; Презентація на нараді Центру тестових технологій, м. Київ, 19 жовт. 2004 p. - K., 2004. -10 c.

8. Савченко О. Уміння учитися як ключова компетентність загальної середньої освіти / Олександра Савченко // Компетентністний підхід у сучасній освіті: світовий досвід та українські перспективи: Бібліотека з освітньої політики / під заг. ред. О. В. Овчарук. - К. : K.I.C., 2004. - 112 с.

9. Хуторской А. В. Ключевые компетенции как компонент личностноориентированной парадигмы образования / А. В. Хуторской // Ученик в общеобразовательной школе. - М.: ИОСО РАО, 2002. - С. 135 -157.

10. Фрумин И. Компетентностное образование / И. Фрумин // Учительская газета. ( 1 марта) - 2005.

11. Bunk G. Teaching Competence in Initial and Continuing Vocational Training in the Federal Republic of Germany / Gerhard P. Bunk. - European Journal Vocational Training. No 1. - January - April 1994/I. - P. 8-14.

12. Crowl T.K., Kaminsky S., Podell D.M. Educational Psychology. Windows on Teaching. - Brown \& Bench mark publishers, 1997. - 416 p. 


\title{
REFERENCES
}

1. Asimov A. G., Schukin A. N. (1999). Slovar Metodicheskih Terminov [Dictionary of the methodological Terms], $365 \mathrm{p}$.

2. Bibik N.M. (2010). Kompetenzii i competentnosti u resultatah pochatkovoji osvity. [Competences in the Results of Primary Education]. No. 9, p.1-4.

3. Bondar V. I. (2011) Formuvannja competentnosti ta concurentnozdatnosti vypusknyka pedagogichnogo VNZ. [The Formation of the Competent and Graduator And and it's Competent Skills] // Journal: Theory and Practice of the Education, $204 \mathrm{p}$.

4. Bondar S. Competenzija osobystosti - integrovanji component navchalnyh dosjagnen uchniv. [The Competence of the Individual as The Integrative Component of its Educational Achievements] / S. Bondar. (2003). Journal: Theory and Practice of the Education No. 2, p.1115.

5. Bunk G. Teaching Competence in Initial and Continuing Vocational Training in the Federal Republic of Germany / Gerhard P. Bunk. - European Journal Vocational Training. No.1. (1994), p.8-14.

6. Crowl T. K., Kaminsky S., Podell D. M. Educational Psycology. Windows of Teaching. (1997), $416 \mathrm{p}$.

7. Frumin 1. (2005) Competentnostnoe obrazovanije, [Competence education].

8. Khutorskoy A. V. (2002). Kluchevyje competentnosti kak component lichnostnoorientirovannoj paradigmy obrazovanija. [Key Competences as the Component of the Personal Paradigm of Education] / A. V. Khutorskoy, p. 135-157.

9. Ovcharuk O. (2003), Kompetentnosti jak kluchovi do onovlennja zmisty osvity. [Competences as the Keys to the Education Innovations] / Oksana Ovcharuk p. 16-27.

10. Pometun O. I. (2004). Kompetentnisniy pidhid do ozinjuvannja rivniv dosjagnen uchniv. [Competence Approach to Evaluate the Levels of Pupils' Achievements] / O. I. Pometun $10 \mathrm{p}$.

11. Savchenko O. Uminnja uchytysja jak kluchova kompetentnist zqgalnoji serednjoi osvity. [The Skill to Study as the Key Competence in the Secondary School] / Oleksandra Savchenko (2004), 112 p.

12. Zinmnya I. A. Kluchevyje kompetentnosti kak rezultativno zelevaja osnova kompetentontnogo podhoda $\mathrm{v}$ obrazovanii. [Key Competences as the Achieved Base of the Competence Approach in the Education] / I.A. Zinnia. (2004). - 42 p.

\section{РЕЗЮМЕ}

\author{
Александра Божок, \\ кандидат педагогических наук, доцент, \\ Национальный педагогический \\ университет имени М. П. Драгоманова \\ Валентин Златников, \\ кандидат педагогических наук, доцент \\ Военный институт Киевского национального \\ университета имени Тараса Шевченко
}

\section{Внедрение компетентностного подхода в образовательное пространство высшей школы}

В статье раскрыто понятие компетентностного подхода в контексте подготовки специалистов по иностранным языкам, а также указаны его виды и особенности. Современной парадигмой выстего образования признан компетентностный подход как один из направлений обновления профессионального образования, призванныий развязывать вопросы, что возникают между потребностями общественной практики и возможностями подготовки компетентных специалистов. 
Ключевые слова: компетентность; компетентностный подход; специалист по
иностранному языку (английский); педагогические условия; профессиональная компетенция.

\section{SUMMARY}

Oleksandra Bozhok,

Candidate of Pedagogical Sciences, Associate Professor

National Dragomanov Pedagogical University

Valentyn Zlatnikov,

Candidate of Pedagogical Sciences, Associate Professor

Military Institute of Taras Shevchenko

National University

\section{The providing of the Competence Approach in the High School Educational Space}

Introduction. The term Competence Approach is defined in the article in the context of the specialists' training of the foreign language knowledge and its peculiarities.

Purpose. In order to define the term "competence approach" we released the content of the meaning "approach" as it is. The essence of this definition is in the context of the numeral approaches, the ways to influence on the members of the educational process. It also includes the ideas, concepts, contests of the didactical objects. Thus the process of the studying relates to the didactical issues.

Methods. In our article we based on the theoretical, didactical methods of investigation, such as retrospective method, method of purposefulness and the mid-disciplinary method. There were additional methods to have been used as well. Among them are: the method of the studying the scientific literature, the analysis of the documents on the question of the education innovations in the pedagogical universities in Ukraine.

Results. This approach is known as the one of the directions of the professional education. This competence approach is gained to solve the problems between the community requirements and the possibilities of the competent specialists. The high school education which contains all main requirements to achieve knowledge, skills and abilities is devoted in the article. The context of learning is built on the students' achievements of the definite level of communicative competence. The examples of the key competences are also given in the article.

Originality. The modern paradigm of the competence approach of high education is devoted to be the general one in the studying and teaching the foreign languages.

Conclusion. The competence approach input to the sphere of education brings the special status not only as the getting the knowledge, but as the using of the following knowledge and skills in the process of individual and professional self-development and self-appraisal.

Key words: competence; competence approach; competent specialist of foreign language (English); pedagogical conditions; professional competence. 